This is the Author's Accepted Manuscript version of a paper published in NATURAL HAZARDS by Springer International Publishing on 10 November 2009. The final publication is available at Springer via http://dx.doi.org/10.1007/s11069-009-9479-8 


\title{
Repeated Glacial-Lake Outburst Floods in Patagonia: An Increasing Hazard?
}

\author{
Alejandro Dussaillant ${ }^{1,2,3,8}$, Gerardo Benito ${ }^{4}$, Wouter Buytaert ${ }^{5,6}$, Paul Carling ${ }^{3}$, Claudio Meier ${ }^{1,8}$, Fabián \\ Espinoza $^{7}$ \\ ${ }^{1}$ Universidad de Concepción, Ingeniería Civil, Barrio Universitario, Casilla 160C, Concepción, Chile \\ ${ }^{2}$ Universidad de Concepción, Centro Ambiental EULA, Concepción, Chile \\ ${ }^{3}$ University of Southampton, School of Geography, SO17 1 BJ Southampton, UK \\ ${ }^{4}$ CSIC, Centro de Ciencias Medioambientales, Serrano 115 bis, 28006, Madrid, Spain \\ ${ }^{5}$ University of Bristol, School of Geographical Sciences, Bristol, UK \\ ${ }^{6}$ Imperial College, London, UK \\ ${ }^{7}$ Dirección General de Aguas, Región de Aysén, Coyhaique, Chile \\ ${ }^{8}$ Centro de Investigaciones en Ecosistemas de la Patagonia, Coyhaique, Chile
}

Corresponding Author: Alejandro Dussaillant (ale.dussaillant@gmail.com)

\section{Abstract}

Five similar glacial-lake outburst floods (GLOFs) occurred in April, October, December 2008, March and September 2009 in the Northern Patagonia Icefield. On each occasion Cachet 2 Lake, dammed by the Colonia Glacier, released circa 200-million $\mathrm{m}^{3}$ water into the Colonia River. Refilling has occurred rapidly, such that further outbreak floods can be expected. Pipeflow calculations of the subglacial tunnel drainage and 1D hydraulic models of the river flood give consistent results, with an estimated peak discharge surpassing $3,000 \mathrm{~m}^{3} \mathrm{~s}^{-1}$. These floods were larger in magnitude than any flood on record, according to gauged data since 1963. However, geomorphological analysis of the Colonia valley shows physical evidence of former catastrophic outburst floods from a larger glacial lake, with flood discharges possibly as high as $16,000 \mathrm{~m}^{3} \mathrm{~s}^{-1}$. Due to potential impacts of climate change on glacier dynamics in the area, jökulhlaups may increase future flood risks for infrastructure and population. This is particularly relevant in view of the current development of hydropower projects in Chilean Patagonia.

Keywords: jökulhlaup; outburst flood; Patagonia; glacial-lake; climate change

\section{Introduction}

Glacial-lake outburst floods, GLOFs (or jökulhlaups in Icelandic) occur due to the sudden release of lake-water impounded by a glacier. During the 2008-2009 hydrologic year, an unexpected sequence of 5 jökulhlaups occurred in the Colonia River valley in Patagonia, Chile (Fig. 1): April 6-7, October 7-8, and December 21-22, 2008; March 4-5 and September 16-17, 2009. Each event drained Cachet 2 Lake, circa 200 million $\mathrm{m}^{3}$, and flooded large parts of the Colonia and Baker River valleys, near the town of Cochrane. The April event, for example, caused considerable damage to farm settlements and stock mortalities, and put the town of Caleta Tortel at the mouth of the Baker River at risk.

Although jökulhlaups have occurred recently in the Patagonian icefields in general (Harrison et al., 2006; Tanaka, 1980; Peña and Escobar, 1983; Andrés Rivera, pers.comm. 2008), the last prior event in the Colonia River basin occurred in the 1960s based in gauge data. The repetitive drainage of Cachet 2 Lake in 20082009 is therefore remarkable, after over 40 years without jökulhlaups occurring in the Colonia valley. The lake refilled in progressively shorter times after each of these similar events. Therefore, further outburst floods can be expected soon.

Jökulhlaup research has mainly focused on their extreme flood flows and modelling (e.g. Alho \& Aaltonen 2008; Osti \& Egashira 2009), while a few studies report that they may contribute with the major part of the sediment flux in glacierized catchments (Desloges \& Church 1992; Old et al. 2005; Russell et al. 2006), and most of them relate to sites in braided sandur plains in Iceland or to moraine breaks in the Himalayas. Severe events have been reported in the Andes, resulting in death losses and damage to infrastructure (e.g. Carey, 2005; Peña and Escobar, 1983).

The Colonia is an outlet glacier located at the eastern side of the North Patagonian Icefield in southern Chile, $47^{\circ} 16^{\prime} \mathrm{S}, 73^{\circ} 13^{\prime} \mathrm{W}$ (Fig. 1). In the upper catchment, both the Colonia and Arco glaciers contribute inflows to Colonia Lake, and dam glacial lakes: Cachet 2 (Colonia Glacier) and Arco (Arco Glacier); these are known to 
60 The combination of enhanced ablation rates, accelerated glacier retreat, and augmented subglacial tunnels due

61 to increased discharge from glaciers, is very likely to contribute to a higher frequency of jökulhlaups (Evans

62 \& Clague, 1994; Richardson \& Reynolds, 2000). Assessing these risks is particularly important in Patagonia

63 in view of the current development of six large-scale hydropower plants in the area (2,300 MW total output,

64 and 2,400 km of transmission lines), one of which would be located immediately downstream of the

65 confluence of the Colonia and Baker rivers.

A detailed reconstruction of historical Colonia Glacier evolution by means of dendrochronology and lichenometry was described by Harrison \& Winchester (2000) and Winchester \& Harrison (2000). These studies report that glacier surface levels began to diminish sometime before 1881, when Arco Lake reached its maximum level and then a large flood occurred. Based on aerial photographs and terrain analysis fieldwork done in 1996 by Harrison \& Winchester (2000), retreat recommenced around 1980 totalling $350 \mathrm{~m}$ (which compares well with the $400 \mathrm{~m}$ retreat estimate by Aniya 2007). They signal calving into Colonia Lake as a significant component of glacier ablation, as opposed to surface melting, and that there is a degree of synchrony between glacier retreat in the western and eastern side of the Northern Patagonia Icefield (NPI), possibly related to precipitation input.

Current glacier retreat trends in Patagonia (Meier \& Dyurgerov 2005; Aniya 2007) coincide with a regional increase in air temperature in the late 1970s evidenced in the instrumental and dendrochronogical record (Rasmussen et al. 2007; Schneider \& Gies, 2004; Villalba et al., 2003; Masiokas et al., 2008). Coincidentally, major jökulhlaups in the southern Andes generally re-started in the 1980s, after almost 2 decades without events (Table 1).

The aim of this work is to report succinctly on multiple events from the same site: pre-historic, historic and modern. We will briefly describe the five repeated 2008-2009 flood events, which indicate a possible return to the pre-1970s jökulhlaup mode and focus on a more specific analysis of the 8 October 2008 event. This analysis was based on gauge data and a field inspection completed 10 days after the event, and the use of several methods to estimate the outburst peak flow in this remote region with scarce data. Finally, we present some evidence of pre-historic jökulhlaups, and consider the implications of future events in the region.

\section{Methods}

The Baker River has been monitored since 1963 by the Dirección General de Aguas of Chile (DGA, the Water Authority). Daily discharge and precipitation data are recorded at the nearest gauging station, located approximately $45 \mathrm{~km}$ downstream from the glacier snout. Fig. 1 shows the station's location, whilst Fig. 3 presents flow and temperature data for the three 2008 GLOFs.

The outburst flood peak on October 8 was estimated (1) from Clague-Mathews relation for jökulhlaups (Ng \& Björnsson, 2003); (2) from subglacial tunnel drainage using pipeflow calculations following Walder \& Costa (1996); (3) at the Lake Colonia outlet using field evidence of flood water marks and hydraulic computations.

Clague-Mathews (1973) provide an empirical equation ( $\mathrm{Ng} \&$ Björnsson, 2003), which is a curve fit from 10 lake outbursts: $Q_{\max }=b V^{a}$, wherein $Q_{\max }$ is peak discharge, in $\mathrm{m}^{3} \mathrm{~s}^{-1}$, and $V$ is lake volume drained, in $\mathrm{hm}^{3}$, with $b=75$ and $a=0.67$. This relationship was complemented with the similar formulation reported by Walder $\&$ Costa (1996), which was fitted to more data, with $b=46$ and $a=0.66$.

Walder \& Costa (1996) provide a method to estimate the discharge through a lateral breach and for a subglacial conduit of circular, near-circular or, roughly, rectangular section (the latter was observed in the Colonia Glacier by visits the day after the October event), such that the following heat transfer equation is valid:

$h_{T} D\left(T_{w}-T_{i}\right)=0.065 k_{w}\left(T_{w}-T_{i}\right)\left(\frac{\rho_{w} U \tilde{D}}{\eta_{w}}\right)$

wherein $h_{T}$ is the heat transfer coefficient, $D$ is the depth of flow, $T_{w}$ and $T_{i}$ are the water temperature and ice temperature respectively, $k_{w}$ is the thermal conductivity of water, $\rho_{w}$ is the density of water, $U$ is mean water 
a rectangular conduit the equivalent conduit diameter is $\tilde{D}=4 D B /(2 D+B)$, where $B$ is the breadth of the conduit. The water temperature in the Baker River during the outburst flood was recorded as $4{ }^{\circ} \mathrm{C}$ (Fig. 3) and the ice temperature can be given as $0^{\circ} \mathrm{C}$. Assuming these values for temperature, then values of the unknowns $h_{T}, k_{w}$ and $\rho_{w}$, which vary according to temperature, follow (see Walder \& Costa, 1996) and the equations can be solved for values of $D$ and $B$.

The Colonia Lake outlet geometry provides the hydraulic control of floodwater hydrographs downstream (Figs. 1 and 3). The outlet channel is approximately straight and a shallow rectangle in section, with a flat gravel bed, but narrows slightly downstream. With a streamflow of c. $50 \mathrm{~m}^{3} \mathrm{~s}^{-1}$, flow was critical during the field survey. Large boulder lag-deposits in the channel and along the banks are consistent with Manning's $n$ roughness coefficients of 0.045 for the river channel and 0.05 for the overbank areas (Barnes, 1967). A previous study reported a similar value for $n(0.042)$ for the streambed, using the Strickler relation $n=D_{90}^{1 / 6} / 26$ between roughness $n$ and sediment size $\left(D_{90}\right)$ sampled in the stream bed and banks (hidroAysén, 2008).

Given the quasi-uniform geometry, criticality, and limited time in this remote location, only two detailed cross sections were surveyed $200 \mathrm{~m}$ apart using GPS. The section furthest downstream (cross section A; Fig. 4C) is where the channel narrows. Flow through the upstream section (cross section B) at the lake outlet was assumed subcritical, with critical flow as a boundary condition at downstream cross section A. Flood water marks left by the October 2008 event (sediment and debris) were surveyed at an elevation of 148-149 m (a.s.l.) at upstream cross section B, and two flood water marks were located at 146 and $148 \mathrm{~m}$ along downstream cross section A. Channel slope is $0.01 \mathrm{~m} \mathrm{~m}^{-1}$. There was no field evidence for significant channel erosion or aggradation during the 2008 floods.

\section{Results and discussion \\ Streamflow data analysis and application of empirical relations for outburst maxima}

The total volume of the flood waves registered at the Baker-Colonia gauging station, was around 230, 190, 125, 200+ and 200 million $\mathrm{m}^{3}$ for the April, October, December 2008 (Fig. 3), and March and September 2009 events, respectively, which is consistent with the size of the Cachet 2 Lake: 230 million ${ }^{3}$ (Casassa et al. 2008). Peak streamflows at the gauge for the 2008 events were approximately $3,600 \mathrm{~m}^{3} \mathrm{~s}^{-1}$, $3,000 \mathrm{~m}^{3} \mathrm{~s}^{-1}$ and $3,050 \mathrm{~m}^{3} \mathrm{~s}^{-1}$, with associated temperature drops (Fig. 3). The March 2009 event exceeded all of these since just before the gauge was damaged it registered 3,800 $\mathrm{m}^{3} \mathrm{~s}^{-1}$ (the last September $16^{\text {th }}$ peak was $3,100 \mathrm{~m}^{3} \mathrm{~s}^{-1}$ ). The contribution of the Baker River can be estimated from its discharge on the previous day, since upstream stations showed no significant changes the days before and during the event. This analysis results in peak discharges in the Colonia River at the confluence for the 2008 floods of c. $2,500 \mathrm{~m}^{3} \mathrm{~s}^{-1}, 2,500$ $\mathrm{m}^{3} \mathrm{~s}^{-1}$, and 2,000 $\mathrm{m}^{3} \mathrm{~s}^{-1}$, respectively. The March 2009 event must have surpassed 2,800 $\mathrm{m}^{3} \mathrm{~s}^{-1}$, and the current last event on September 2009 had a peak contribution of 2,500 $\mathrm{m}^{3} \mathrm{~s}^{-1}$.

Using the Clague-Mathews formulation for the 2008 events results in peak discharges around 2,600, 2,500 and $1,900 \mathrm{~m}^{3} \mathrm{~s}^{-1}$, respectively, Estimations are significantly lower using Walder \& Costa formulation, due to the obvious effect of a lower multiplication coefficient. The difference between outcomes is attributed, as reported in the literature, to the fact that these equations are empirical fits to several case studies, while not related to the site-specific effects of the trigger mechanism and conduit geometry (Roberts, 2005). However, the estimations using the former are consistent with the peak flows computed above for the Colonia at the Baker confluence.

\section{Field observations}

The planview of the Colonia valley is given in Fig. 1. The direction of the $7 \mathrm{~km}$ long outbreak through ice tunnels is indicated on Figs. 1 and 2. Oblique images of Cachet 2 Lake and the glacier surface after the jökulhlaup event of 8 October show no evidence of sediment laden water flowing over the glacier surface from the lake. Rather, photographs show a distinct area of major ice-collapse circa $25 \mathrm{~m}$ in width -that is roughly transverse to the direction of the glacier flow- and depth $4 \mathrm{~m}$ (Fig. 2; Fernando Guzmán, DGAChile, pers. comm. 2008) in the surface of the glacier but extending to the $65 \mathrm{~m}$ high ice-wall that impounded the lake. This collapse area narrows rapidly and then is terminated where it intersects with a crevasse. Such areas of linear ice-collapse have been reported subsequent to other jökulhlaups discharging through ice tunnels (Walder \& Costa, 1996; Kessler \& Anderson, 2004). The presence of a pre-existing sub-glacial conduit or complex of conduits for jökulhlaup drainage is not unreasonable (Mäkinen and Palmu, 2008). 
Solving equation 1 with values for $D$ and $B$ of respectively $4 \mathrm{~m}$ and $25 \mathrm{~m}$, yields a discharge of circa $2,500 \mathrm{~m}^{3} \mathrm{~s}^{-1}$. Equation 1 is most sensitive to values of $D$ and $B$. Assuming that the dimensions of the collapse in the ice surface reflect a somewhat larger sub-glacial conduit, Equation 1 is less-well balanced (c. $10 \%$ error due to mainly uncertainty in depth), yielding discharges in the range of 3,780 to $4,550 \mathrm{~m}^{3} \mathrm{~s}^{-1}$ with a pipe flow speed of $25 \mathrm{~ms}^{-1}$. Thus, the pipeflow calculation is roughly consistent with estimations based on the ClagueMathews equation and streamflow observations further downstream, as reported above.

Calculations at the outlet of Colonia Lake suggest a higher peak discharge. Since the outlet reach is steep (1.0 $\%)$ it was safe to assume supercritical slope and thus even a single section would have been enough to estimate peak flow using slope data, regardless of roughness values. Critical flow must occur somewhere at the outlet, we surveyed two sections, and estimated peak flow at each one of them using the high water marks (Fig. 4). Considering also bathymetric uncertainties, peak discharges computations yield 3,100-4,500 $\mathrm{m}^{3} \mathrm{~s}^{-1}$, with a reasonable approximation being the average: $3,800 \mathrm{~m}^{3} \mathrm{~s}^{-1}$.

\section{Evidence of previous outburst catastrophic flooding}

Field inspection at the outlet of Colonia Lake shows geomorphic evidence of ancient large floods carving the lake outlet (Fig. 4). On the right margin of the Colonia River outlet, these palaeoflood indicators consist of high elevation flood-scoured channelways with vertical banks, filled with imbricated boulders and carved on Pleistocene moraine deposits. On the left margin, a large boulder bar contains 4-5 m diameter imbricated boulders (Fig. 4), indicative of ancient catastrophic outburst floods.

An estimation of the potential discharges carving these morphologies was done using HEC-RAS both (1) with the current topography and (2) assuming that the entrenched Colonia Lake outlet channel was developed by flood incision, and considering a pre-incision topography with channel elevation matching the boulder bar surface. In scenario 1, a flood discharge of $16,000 \mathrm{~m}^{3} \mathrm{~s}^{-1}$ is required to reach the upper spillway channel bottom placed at the right outlet margin. In scenario 2, the discharge required to reach the high elevation flood channel is 7,500 $\mathrm{m}^{3} \mathrm{~s}^{-1}$. According to Walder and Costa (1996) equations, a peak discharge of 7,500$16,000 \mathrm{~m}^{3} \mathrm{~s}^{-1}$ would require a lake volume of $100-450$ million $\mathrm{m}^{3}$ assuming a drain through a subaerial breach, usually at the glacier terminus, and of 2,250-7,000 million $\mathrm{m}^{3}$ for a drain through a subglacial tunnel. The only obvious source of water for such a flood is lake Arco (Fig. 1).

Arco Lake was much larger in the past, as concluded by Harrison \& Winchester (2000) and Winchester \& Harrison (2001) based on dendrochronology and lichenometry, as well as the horizontal trimline also observed by us: approximately $120 \mathrm{~m}$ above the 1996 water level, marked by an abrupt change in plant cover that runs horizontally along both sides of the valley. Arco may be speculated as the potential source of water for the catastrophic flood (Tanaka, 1980) possibly producing much larger floods that would sustain our estimate of a palaeo-discharge surpassing 7,500 $\mathrm{m}^{3} \mathrm{~s}^{-1}$ (Harrison and Winchester, 2000). The lack of old tree vegetation we observed on the boulder bar and on the spillway channel may be indicative of a historical flood carving these landforms.

\section{Potential implications for dam safety and life-span in a changing Patagonia}

These 5 repeated glacial-lake outburst floods in Patagonia entail further practical safety and risk assessment considerations for the three billion dollar plan to build four hydropower stations on the Baker River (Aysén Hydroelectric Project), one located downstream of the jökulhlaup source. The dam safety check flood (10,000-year flood; ICOLD, 1995) was estimated as 6,724 $\mathrm{m}^{3} \mathrm{~s}^{-1}$ in the Environmental Impact Study for the dams (HidroAysén, 2008), based on a probabilistic frequency analysis of the streamflow gauge record from 1963 till 2007.

Despite being estimated with a time series lacking the recent outburst floods, the check flood for the dam is considerably higher than those resulting from the 2008 jökulhlaups, taking into consideration Baker baseflow during the events. However, the safety check flood should represent the most extreme flood conditions that the dam structure could support without failure, including a low safety margin. Hence, ancient and historical jökulhlaups herein described (which could range between 7,500 and $16,000 \mathrm{~m}^{3} \mathrm{~s}^{-1}$ ) require further investigation before deriving an upper discharge limit.

Finally, from our aerial flights (e.g. Fig 2) and field reconnaissance, it is evident that the braided Colonia River carries a very large sediment load. At its confluence (Fig. 2), the bed material contributed by the 
Colonia constricts the Baker to a width of only about $50 \mathrm{~m}$ from its average upstream value of about 250 to $300 \mathrm{~m}$. Large loads delivered by extreme floods could have important consequences for the life expectancy of the planned reservoir: but, no sediment budgets were carried out in the studies for the dams (HidroAysén, 2008). However, estimating sediment transport due to jökulhlaups is a challenging necessity (Desloges \& Church 1992; Old et al. 2005; Russell et al. 2006).

\section{Summary and Conclusions}

Five very recent glacial-lake outburst floods (jökulhlaups), briefly reported here, occurred on 7 April, 8 October, and 21 December 2008, and on 5 March and 16 September 2009, emptying the Cachet 2 Lake in Chilean Patagonia, in each occasion releasing circa 200 million $\mathrm{m}^{3}$ of water into the Colonia River. Reconstruction of the October 2008 flood wave through literature formulations, geomorphological observations and hydraulic simulation of the outbreak, reveal similar results (Table 2): peak flow is estimated between 2,500 and $3,500 \mathrm{~m}^{3} \mathrm{~s}^{-1}$.

The consistency gives credibility to the hypothesis that the outbreak occurred through a subglacial tunnel. However, it is surmised that to evacuate a peak flow of circa $3,000 \mathrm{~m}^{3} \mathrm{~s}^{-1}$ through $7 \mathrm{~km}$ of glacier ice, from the lake to the snout of the Colonia Glacier, then the enlarged crevasse must intersect a pre-existing sub-glacial drainage conduit (Kessler \& Anderson, 2004). Additionally, given the partial rising-limb gauge record, it can be expected that the event on 5 March 2009 exceeded $4,000 \mathrm{~m}^{3} \mathrm{~s}^{-1}$.

These repeated GLOFs are particularly relevant for re-assessing risk estimations for planned infrastructure in Patagonia. There is a dam project proposed immediately downstream where the Colonia River meets the Baker River, part of a 6-dam project. The EIS report (HidroAysén, 2008) proposes a safety check flood $\left(10,000\right.$ years return period) between 5,500 and $8,000 \mathrm{~m}^{3} \mathrm{~s}^{-1}$, and does not estimate the sediment contributions from tributaries to the Baker. Given the magnitude of the outburst floods that occurred before the flow gauging started, this check flood may well underestimate the peak discharges from future jökulhlaup events. The large sediment loads contributed by the Colonia River could also result in increased reservoir sedimentation, affecting the life expectancy of the planned dam. In general, more studies are needed regarding the impact of these recent GLOFs in the water, sediment and nutrient budgets of the river (and fjord) ecosystems, as well as risk to existing and planned human infrastructure in Patagonia.

\section{Acknowledgements}

PBCT-Conicyt project ACI-70, with funding provided by the World Bank, supported this preliminary research. We also thank the field support from Instituto de Investigaciones en Ecosistemas Patagónicos (www.ciep.cl) and Dirección General de Aguas, DGA.

\section{References}

Alho P \& J Aaltonen (2008). Comparing a 1D hydraulic model with a 2D hydraulic model for the simulation of extre glacial outburst. Hydrol. Proc. 22, 1537-1547.

Aniya, M. (2007). Glacier variations of Hielo Patagónico Norte, Chile, for 1944/45 - 2004/05. Bull. Glaciol. Res. 24, 59-70.

Aniya, M. and R. Naruse (2001). Overview of glaciological project in Patagonia during 1998 and 1999: Holocene glacier variations and their mechanisms. Bull. Glaciol. Res. 18, 71-78.

Barnes, H. H. (1967), Roughness characteristics of natural channels. U.S. Geological Survey Water-Supply paper 1849, 213 pp, USGS, Denver, CO.

Carey M (2005). Living and dying with glaciers: people's historical vulnerability to avalanches and outburst floods in Perú. Glob. Planet. Change 47(2-4): 122-134.

Casassa, G., Leidich J., Rivera A., Wendt J., Escobar F., Guzmán F., Carrasco J. and López P. (2008). Sudden drainage of glacial Lake Cachet 2, Patagonia. EGU von Humboldt conference, November 2008, Santiago, Chile.

Desloges \& Church 1992. Geomorphic implications of glacier outburst flooding: Noeick River valley, British Columbia. Can. J. Earth Sci. 29, 551-564

Dussaillant A., X. Rojas, M Arias, O. Maturana and W Buytaert (2009), Natural flow regime studies under low information contexts and ungauged catchments: application to Baker River basin, Patagonia, Chile, VII Ecohydraulics symposium, HEIC January 2009 conference, Concepción, Chile.

Dyurgerov MB \& MF Meier (2005). Glaciers and the Changing Earth System: a 2004 Snapshot. Institute of Arctic and Alpine Research, University of Colorado, Boulder, USA. Occasional Paper 58. INSTAAR/OP58 ISSN 0069-6145. 118 pp. 
Evans, S. and J. Clague (1994), Recent climate change and catastrophic geomorphic processes in mountain environments, Geomorphology 10, 107-128.

Fernández, P., Fornero, L., Maza, J., Rollan, R. A., Yáñez, H., Núñez, M.S. and de Alpeggiani, E. B. (1985), Hidrología del río Mendoza: Simulación matemática del las hipótesis de rotura del dique natural formado por el Glaciar Grande del Nevado del Plomo y del traslado de las crecientes desde el glaciar hasta 200 metros aguas abajo de Alvarez Condarco, Instituto Nacional de Ciencia y Técnicas Hídricas, Centro Regional Andino, Mendoza, Argentina, 135pp.

Fernández, P.C., Fornero, L., Maza, J. and Yañez, H. (1991), Simulation of flood waves from outburst of glacier-dammed lake, J. Hydraulic Eng., 117, 42-53.

Harrison, S., and V. Winchester (2000), Nineteenth- and Twentieth-Century Glacier Fluctuations and Climatic Implications in the Arco and Colonia Valleys, Hielo Patagónico Norte, Chile, Arct. Antarct. Alp. Res. 32, 55-63.

Harrison, S., N. Glasser, V. Winchester, E. Haresign, C. Warren, and K. A. Jansson (2006), Glacial lake outburst flood associated with recent mountain glacier retreat, Patagonian Andes, The Holocene 16, 611620 .

HidroAysén (2008), Estudio de Impacto Ambiental Proyecto hidroAysén, Environmental Impact Study available in Spanish at http://www.e-seia.cl.

HEC (1995), HEC-RAS, River Analysis System, Hydraulics Reference Manual. Hydrologic Engineering Center, Davis, CA.

ICOLD (1995), Dam failures, Statistical Analysis Bulletin 99, ICOLD, Paris.

Kessler, M.A. and R.S. Anderson (2004), Testing a numerical glacial hydrological model using spring speedup events and outburst floods. Geoph. Res. Let., 31, L18503, doi:10.1029/2004GL020622.

Lliboutry, L. (1956), Nieves y Glaciares de Chile, fundamento de glaciologia, Santiago, Chile. Ediciones de la Universidad de Chile (in Spanish), $417 \mathrm{pp.}$

Mäkinen, J., and J. P. Palmu (2008), Collapse of sediment-filled crevasses associated with floods and mass flows in the proximal zone of the Pernunnummi sandurdelta, III Salpausselkä, SW Finland, Quaternary Sci.Rev., 27, 1992-2011.

Masiokas, M.H., R. Villalba, R. H. Luckman, M. E. Lascano, S. Delgado, and P. Stepanek (2008), $20^{\text {th }}-$ century glacier recession and regional hydroclimatic changes in northwestern Patagonia, Global Planet. Change, 60, 85-100.

Ng F. and H. Björnsson (2003), On the Clague-Mathews relation for jökulhlaups. J. Glaciol. 49, 165, 161172.

Old, G.H., D.M. Lawler \& A. Snorrason. (2005). Discharge and suspended sediment dynamics during two jökulhaups in the Skafta' River, Iceland. Earth Surf. Process. Landf., 30 ,11, 1441-1460.

Osti R \& S Egashira. (2009) Hydrodynamic characteristics of the Tam Pokhari Glacial Lake outburst flood in the Mt. Everest region, Nepal. Hydrol. Proc. DOI: 10.1002/hyp. 7405

Peña, H. and F. Escobar (1983a), Análisis de una crecida por vaciamiento de una represa glacial, VI Congreso, Sociedad Chilena de Ingeniería Hidráulica, 375-392.

Peña, T. H., and C. F. Escobar (1983b), Análisis de las crecidas de Río Paine, XII región, Publicación Interna Estudios Hidrológicos No. 83/7, Dirección General de Aguas, Ministerio de Obras Públicas, Santiago, Chile, 78 pp. (in Spanish).

Peña, H. and F. Escobar (1987), Análisis del aluvión de mayo de 1985 del río Manflas, cuenca del río Copiapó, Publicacion Interna Estudios Hidrológicos 87/3, Dirección General de Aguas, Ministerio de Obras Públicas, Chile, 14pp. (in Spanish).

Rasmussen L., H. Conway \& C. Raymond (2007), Influence of upper air conditions on Patagonia Icefields, Global Planet. Change, doi: 10.1016/j.gloplacha.2006.11.025

Richardson, S.D. and J. M. Reynolds (2000), An overview of glacial hazards in the Himalayas, Quatern. Int., 65-66, 31-47.

Roberts, M.J. (2005), Jökulhlaups: a reassessment of floodwater flow through glaciers, Reviews of Geophysics, 43 RG1002.

Russell AJ, MJ Roberts, H Fay, PM Marren, NJ Cassidy, FS Tweed \& T Harris (2006). Icelandic jökulhlaup impacts: Implication for ice-sheet hydrology, sediment transfer and geomorphology. Geomorphology 75, $33-64$.

Schneider, C. and D. Gies (2004), Effects of El Niño-Southern Oscillation on southernmost South America precipitation at $53^{\circ} \mathrm{S}$ revealed from NCEP-NCAR re-analyses and weather station data, Int. J. Climatol. 24, 1057-1076. 
Tanaka, K. (1980), Geographic Contribution to a Periglacial Study of the Hielo Patagónico Norte with Special Reference to the Glacial Outburst Originated from Glacier-Dammed Lago Arco, Chilean Patagonia, 97 pp., Centre Co. Ltd., Tokyo.

United Nations (2002), Global Warming Triggers Glacial Lakes Flood Threat. UN Chronicle, Volume 39, United Nations.

350 Walder, J.S., and J.E. Costa (1996), Outburst floods from glacier-dammed lakes: The effect of mode of lake drainage on flood magnitude, Earth Surf. Proc. Land., 21, 701-723.

Villalba R., A Lara, JA Boninsegna, M Masiokas, S Delgado, JC Aravena, FA Roig, A Schmelter, A Wolodarsky \& A Ripalts. 2003. Large-scale temperature changes in the southern Andes: $20^{\text {th }}$-century variations in the context of the past 400 years. Climatic Change 59: 177-232. dating of geomorphological events on the east side of the North Patagonian Icefield, Chile, Geomorphology, 34, 181-194. 


\section{Symbols}

$362 a, b=$ empirical coefficients for Clague-Mathews and Walder \& Costa equations

$363 h=$ head loss

$364 \lambda=$ friction factor

$365 K=$ head loss coefficient

$366 D=$ diameter of conduit

$367 R=$ hydraulic radius $=D / 4 \Phi$

$368 U=$ bulk flow velocity $=Q / \pi D^{2} / 4 \phi$

$369 Q=$ discharge

$370 g=$ acceleration due to gravity

$371 k_{s}=$ equivalent sand grain roughness for ice walls

$372 v=$ kinematic viscosity

$373 R e=$ Reynolds number $=U D / v$

$374 \Phi=$ pipe shape factor 
375 Table 1: Selected major historical jökulhlaups in the Southern Andes

\begin{tabular}{|c|c|c|c|c|c|}
\hline Glacier/lake & $\begin{array}{l}\text { Volume } \\
\mathrm{hm}^{3}\end{array}$ & Failures & $\begin{array}{l}\text { River (approx. } \\
\text { latitude) }\end{array}$ & $\begin{array}{l}\text { Discharge } \\
\mathrm{m}^{3} \mathrm{~s}^{-1}\end{array}$ & References \\
\hline \multirow[t]{2}{*}{$\begin{array}{l}\text { Nevado del } \\
\text { Plomo }\end{array}$} & 53 & 1934 & $\begin{array}{l}\text { Mendoza } \\
\left(33^{\circ} \mathrm{S}\right)\end{array}$ & 2,700 & $\begin{array}{l}\text { Fernández et al. } \\
1985\end{array}$ \\
\hline & $35 ; 21 ; 20$ & $\begin{array}{l}1985 \text { (Feb; } \\
\text { Feb; Mar) }\end{array}$ & Mendoza & $284 ; 277 ; 184$ & $\begin{array}{l}\text { Fernández et al. } \\
1985,1991\end{array}$ \\
\hline $\begin{array}{l}\text { Moreno - L. } \\
\text { Argentino }\end{array}$ & $\begin{array}{l}2,000 ; 5,000 ; \\
3,800\end{array}$ & $\begin{array}{l}1953 ; 1956 ; \\
1966\end{array}$ & $\begin{array}{l}\text { Santa Cruz } \\
\left(49^{\circ} \mathrm{S}\right)\end{array}$ & $\begin{array}{l}12,000 ; 20,000 ; \\
15,000\end{array}$ & $\begin{array}{l}\text { Walder \& Costa } \\
1996\end{array}$ \\
\hline Juncal & $?$ & 1954 & $\begin{array}{l}\text { Olivares } \\
\left(33^{\circ} \mathrm{S}\right)\end{array}$ & 400 & $\begin{array}{l}\text { Humberto Peña } \\
\text { pers.comm. } 2008\end{array}$ \\
\hline Cachapoal & $1.5-2$ & $\begin{array}{l}1981 \text { ( } 8 \text { floods } \\
\text { in } 19 \text { days) }\end{array}$ & $\begin{array}{l}\text { Cachapoal } \\
\left(34^{\circ} \mathrm{S}\right)\end{array}$ & 150 & $\begin{array}{l}\text { Humberto Peña } \\
\text { pers.comm. } 2008\end{array}$ \\
\hline Manflas & 5 & 1981 & $\begin{array}{l}\text { Seco, Manflas } \\
\left(28^{\circ} \mathrm{S}\right)\end{array}$ & 11,000 & $\begin{array}{l}\text { Peña \& Escobar } \\
1987\end{array}$ \\
\hline $\begin{array}{l}\text { Dickson - L. } \\
\text { Dickson (SPI) }\end{array}$ & $220 ; 230 ; 290$ & $\begin{array}{l}\text { Jan 1982; Dec } \\
\text { 1982; Mar } \\
1983\end{array}$ & $\begin{array}{l}\text { Paine } \\
\left(50^{\circ} \mathrm{S}\right)\end{array}$ & $360 ; 330 ; 340$ & $\begin{array}{l}\text { Peña \& Escobar, } \\
1983 a, b\end{array}$ \\
\hline Calafate (NPI) & $?$ & 1987 or 1989 & $\begin{array}{l}\text { Soler } \\
\left(43^{\circ} \mathrm{S}\right)\end{array}$ & $?$ & $\begin{array}{l}\text { Aniya \& Naruse } \\
2001\end{array}$ \\
\hline $\begin{array}{l}\text { León } \\
(\mathrm{NPI})\end{array}$ & $1.5-2$ & 2000 & $\begin{array}{l}\text { Los Leones } \\
\left(44^{\circ} \mathrm{S}\right)\end{array}$ & $?$ & $\begin{array}{l}\text { Harrison et al. } \\
2006\end{array}$ \\
\hline $\begin{array}{l}\text { Colonia (NPI) } \\
\text { - L. } \\
\text { Cachet/Arco }\end{array}$ & $100-265 ?$ & $\begin{array}{l}1896 / 1897, \\
1914 / 1917, \\
1928-1958 \\
1944 \ldots 1953, \\
1955,1956, \\
1958,1963 \\
11 \text { Jan } 1964 \\
\text { and } 3 \text { Mar } \\
\text { 1966 (+ } \\
\text { probably } 4 \\
\text { Mar 1965 and } \\
7 \text { Jan 1967, yet } \\
\text { smaller floods) }\end{array}$ & $\begin{array}{l}\text { Colonia/Baker } \\
\left(47^{\circ} \mathrm{S}\right) \\
\text { Colonia/Baker }\end{array}$ & $\begin{array}{l}\text { c. } 2,000(3,100 \text { in } \\
\text { Baker River, } \\
\text { baseflow c. } 1,200 \\
\left.\mathrm{~m}^{3} \mathrm{~s}^{-1}\right)\end{array}$ & $\begin{array}{l}\text { Tanaka 1980; } \\
\text { Winchester \& } \\
\text { Harrison } 2000 \\
\text { DGA pers. com.; } \\
\text { Lliboutry } 1956 \\
\text { This paper, from } \\
\text { gauge data }\end{array}$ \\
\hline \multirow[t]{5}{*}{$\begin{array}{l}\text { Colonia - } \\
\text { Cachet } 2\end{array}$} & 230 & 2008 (Apr 7) & $\begin{array}{l}\text { Colonia/Baker } \\
\text { Lago Cachet } 2\end{array}$ & $\begin{array}{l}\text { c. } 2,500(3,600 \text { in } \\
\text { Baker River, } \\
\text { baseflow c. } 1,100 \\
\left.\mathrm{~m}^{3} \mathrm{~s}^{-1}\right)\end{array}$ & $\begin{array}{l}\text { This paper, by } \\
\text { gauge data and } \\
\text { Clague-Mathews } \\
\text { formulation }\end{array}$ \\
\hline & 190 & 2008 (Oct 8) & $\begin{array}{l}\text { Colonia/Baker } \\
\text { Lago Cachet } 2\end{array}$ & $\begin{array}{l}\text { c. } 2,500(3,000 \text { in } \\
\text { Baker River, } \\
\text { baseflow circa } \\
\left.500 \mathrm{~m}^{3} \mathrm{~s}^{-1}\right)\end{array}$ & $\begin{array}{l}\text { This paper, using } \\
\text { relations, gauge } \\
\text { data, \& hydraulic } \\
\text { model }\end{array}$ \\
\hline & 125 & 2008 (Dec 21) & $\begin{array}{l}\text { Colonia/Baker } \\
\text { Lago Cachet } 2\end{array}$ & $\begin{array}{l}\text { c. } 2,000(3,050 \text { in } \\
\text { Baker River, } \\
\text { baseflow c. } 1,050 \\
\left.\mathrm{~m}^{3} \mathrm{~s}^{-1}\right)\end{array}$ & $\begin{array}{l}\text { This paper, by } \\
\text { gauge data and } \\
\text { Clague-Mathews } \\
\text { formulation }\end{array}$ \\
\hline & $>200$ & 2009 (Mar 5) & $\begin{array}{l}\text { Colonia/Baker } \\
\text { Lago Cachet } 2\end{array}$ & $\begin{array}{l}>2,800(>3,800 \\
\text { Baker, damaged } \\
\text { gage, baseflow } \\
\left.\text { circa } 1,000 \mathrm{~m}^{3} \mathrm{~s}^{-1}\right)\end{array}$ & $\begin{array}{l}\text { This paper, by } \\
\text { stream gage data } \\
\text { (incomplete } \\
\text { record) }\end{array}$ \\
\hline & 200 & 2009 (Sep 16) & $\begin{array}{l}\text { Colonia/Baker } \\
\text { Lago Cachet } 2\end{array}$ & c. 2,500 & $\begin{array}{l}\text { This paper, by } \\
\text { gauge data }\end{array}$ \\
\hline
\end{tabular}

377 Notes:

378 1. Many events also reported in Walder \& Costa (1996)

379 2. NPI: Northern Patagonia Icefield. SPI: Southern Patagonia Icefield 
380 Table 2: Estimation results for peak flows for the October 2008 Cachet 2 Lake outburst 381 flood, Patagonia

382

\begin{tabular}{|c|c|c|c|c|}
\hline & $\begin{array}{c}\text { Clague- } \\
\text { Mathews } \\
\text { (empirical) }\end{array}$ & $\begin{array}{l}\text { Pipeflow } \\
\text { (physical) }\end{array}$ & $\begin{array}{c}\text { Hydrograph } \\
\text { analysis } \\
\text { (data) }\end{array}$ & $\begin{array}{l}\text { Hydraulic } \\
\text { (physical) }\end{array}$ \\
\hline $\begin{array}{l}\text { Most sensitive } \\
\text { parameter or } \\
\text { variable: }\end{array}$ & $\begin{array}{c}\mathrm{V}: 200-230 \mathrm{x} \\
10^{6} \mathrm{~m}^{3}\end{array}$ & D: $3-6 \mathrm{~m}$ & $\begin{array}{l}\text { Rating curve } \\
\text { fit }\end{array}$ & $\begin{array}{l}\text { Cross section } \\
\text { geometry }\end{array}$ \\
\hline $\begin{array}{l}\text { Peak discharge } \\
\left(\mathrm{m}^{3} \mathrm{~s}^{-1}\right):\end{array}$ & 2,500 & 2,700 & 3,000 & 3,800 \\
\hline Range: & $2,400-2,800$ & $2,500-4,500$ & $2,700-3,200$ & $3,100-4,500$ \\
\hline
\end{tabular}

383

384 
386 Figure 1: Elevation map of the study basin (m). Glaciers are indicated in white. Arrows: flow direction of the jökulhlaups (note arrow detailing viewpoint of aerial photograph $2 \mathrm{~A}$ ). $・$ = location of the DGA hydrometeorological station on the Baker River

Figure 2: Aerial photographs of Colonia valley taken 8 October 2008, during the receding period of the jökulhlaup event (17:00-19:00 local time). A: oblique view of Colonia Glacier and empty Cachet 2 Lake, showing drainage point and flow directions (viewpoint detailed in Fig. 1). B: image showing collapsed tunnel. C: Colonia confluence with Baker mainstem during receding flood (source: DGA - Aysén)

Figure 3: Discharge and water temperature in the Baker-Colonia gage during the jökulhlaup events of April, October and December 2008. Note temperature drops due to Colonia enhanced glacial input to Baker River.

Figure 4: Lake Colonia outlet reach containing field evidence of 2008 flood water marks and of previous catastrophic flooding. A: Cross-section used on the one-dimensional hydraulic model calculations, showing the flood water level for the 2008 flood(s) and evidences of ancient jökulhlaups (spillway channel and boulder bar). Discharge estimation for the ancient flooding was based both on the current topography, as well as a likely pre-incision topography with channel elevation matching the boulder bar surface (point line between two grey dots). B: Rating curve from hydraulic analysis showing the minimum discharge ranges associated with the 2008 jökulhlaups and with previous palaeoflood stage indicators. C: Upstream view of the Colonia outlet showing the 2008 flood level, the boulder bar and the flood-scoured channelways. D: Boulder bar containing large boulders (4-5 $\mathrm{m}$ in diameter) related to high-energy catastrophic outburst floods. 


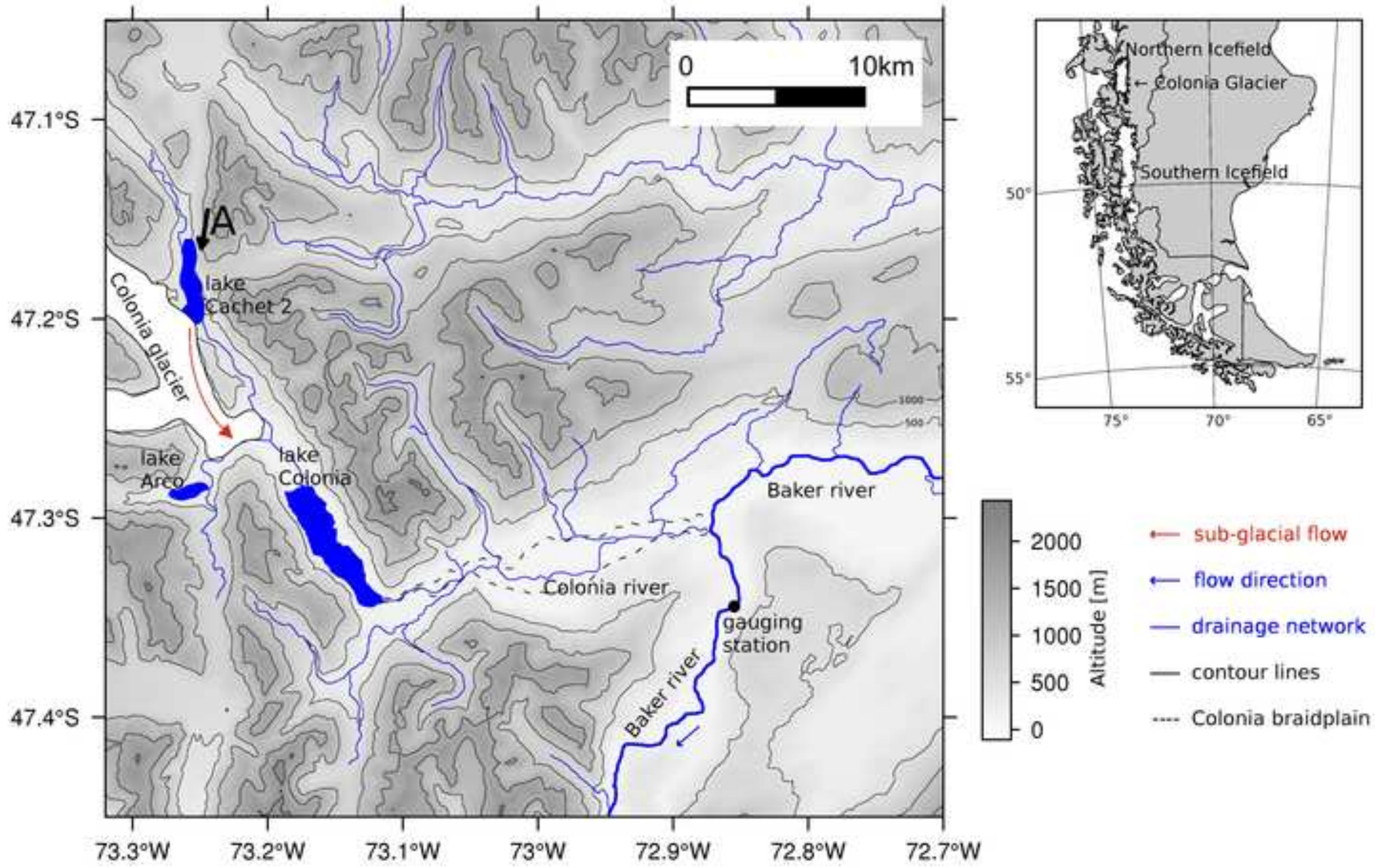


line figure
Click here to download high resolution image

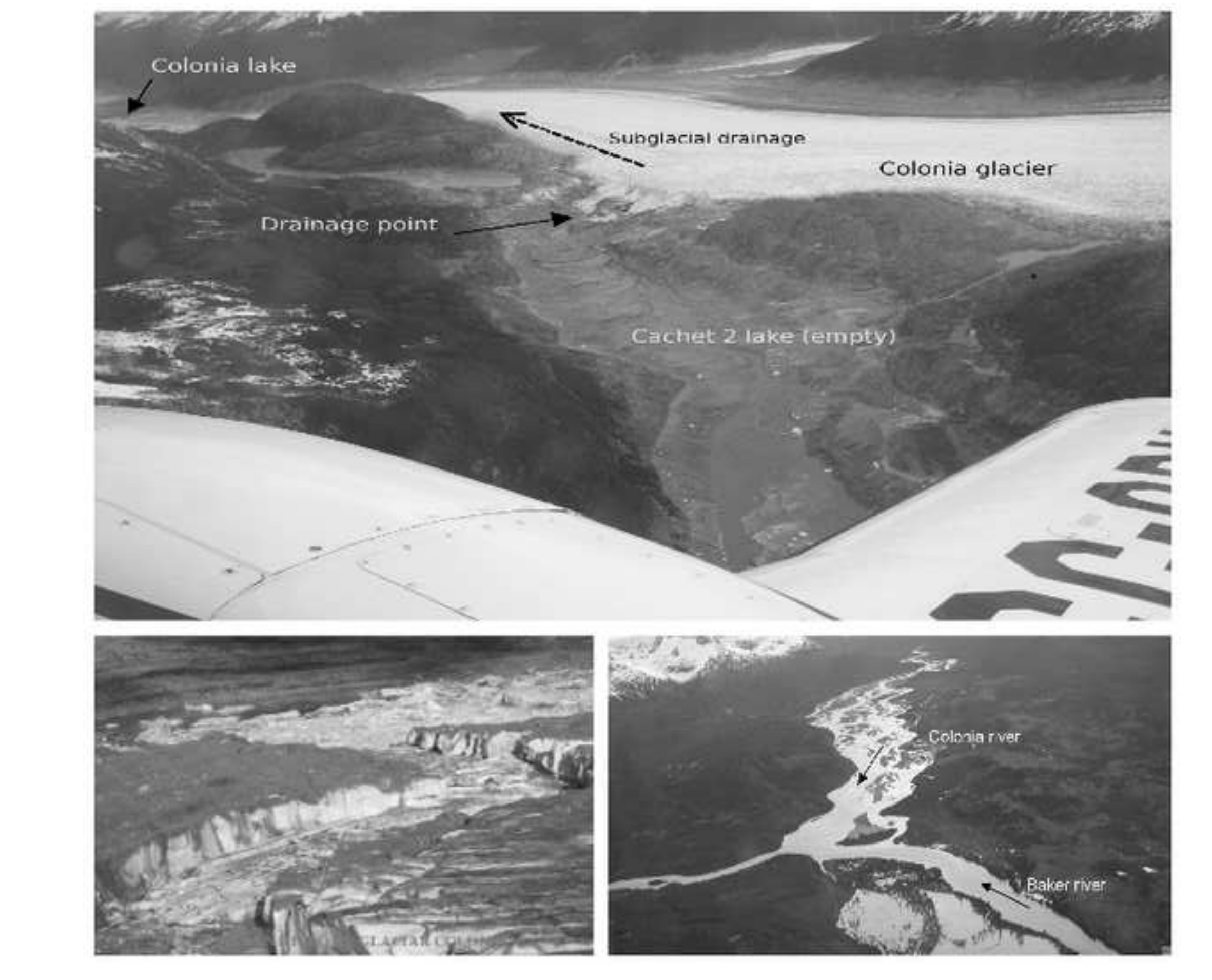



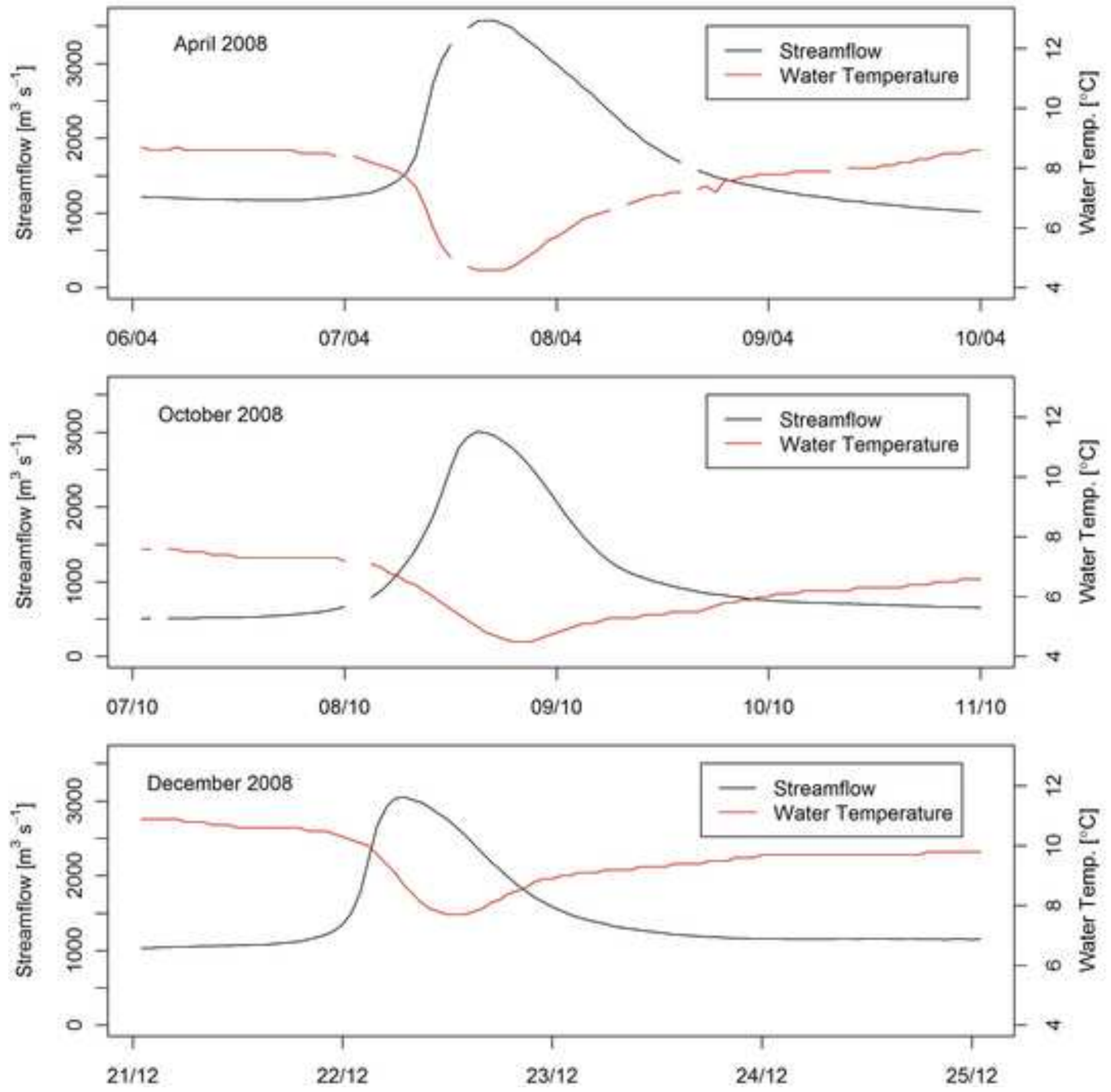

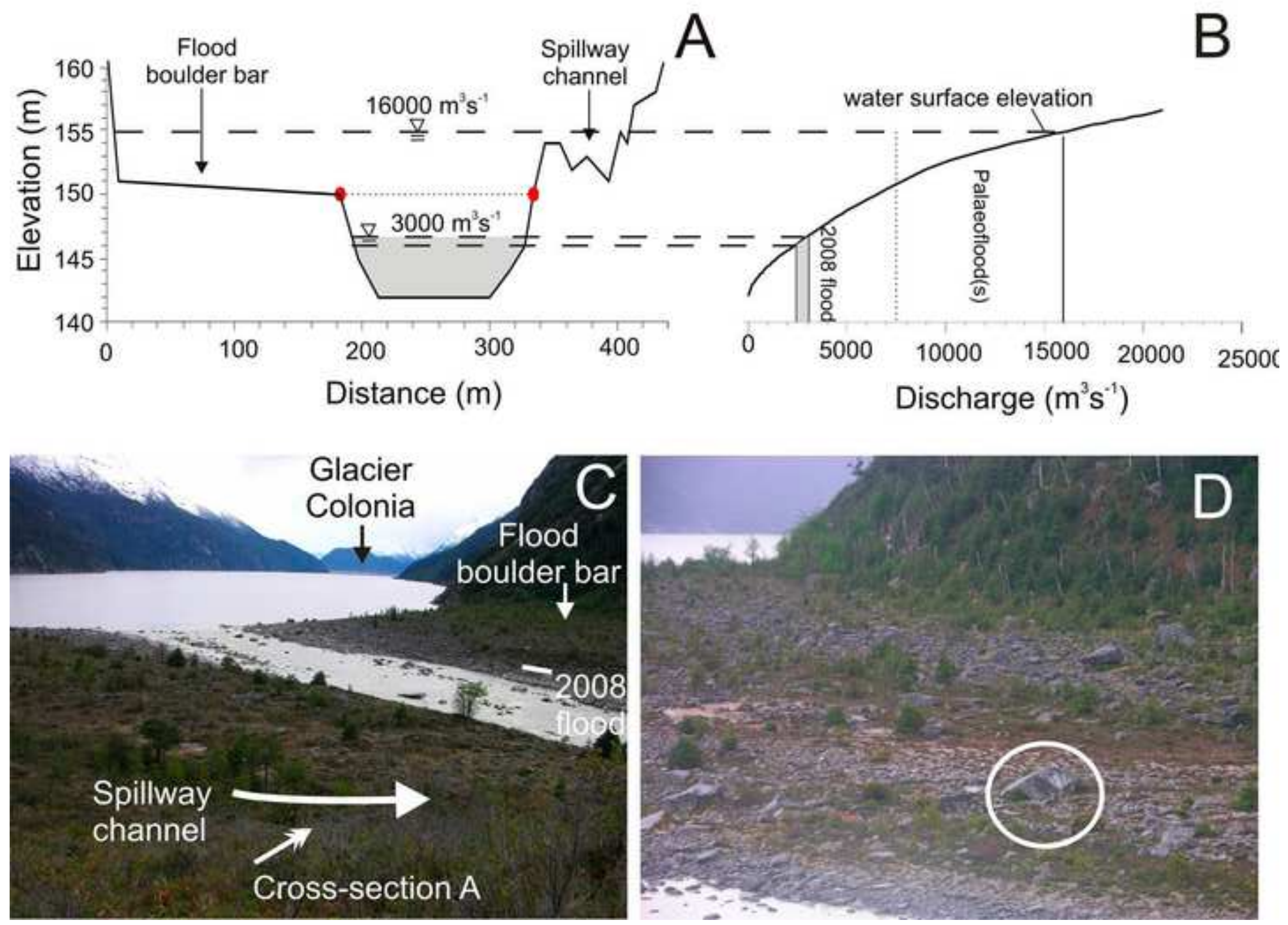